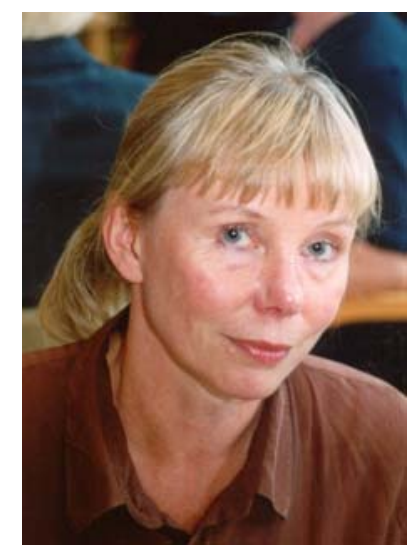

Anja Heikkinen

\section{Huolenpitoa ja hallintaa}

$\mathrm{M}$ iksi tehdä erilaisuudesta numeroa (A)ikuiskasvatuksessa? "Kaikkihan me olemme erilaisia". Erilaisuuksien moninaisuus näyttää kasvatuksen ja koulutuksen valtavirrassa kuitenkin konvergoituvan kohti elinikäistä oppijuutta, kansalaisuuden ei enää kovin uutta muotoa. Erilaiseksi tunnistamisen ja tunnustamisen kriteereinä ovat oppimisen vaikeudet ja ongelmat. Niiden diagnosointiin ja hoitamiseen tarvitaan enenevä joukko asiantuntijoita, joiden toiminnan oikeuttaa oppimisvaikeuksia ja -ongelmia koskeva tutkimus ja tieteellinen koulutus.

Eikö tämä ole edistystä? Yhdessä eri Euroopan maita koskeneessa vertailevassa tutkimuksessani (Re-enter, Re-integration) kävi ilmi, että Suomessa on yleisempää lähestyä kaikenlaisia yhteiskunnan, koulutuksen ja työn valtavirran kannalta ongelmaisia ihmisiä erityispedagogiselta kannalta. Monissa muissa maissa ongelmien ratkominen kuuluu perheelle tai sukulaisverkostolle, sosiaalityöntekijöille, sosiaalipedagogeille ja nuorisotyöntekijöille. Niin sanottu integroiva kasvatuskin tapahtuu enimmäkseen eristämällä ongelmaiset omiin laitoksiin ja toimintaohjelmiin, joiden kautta he hyvässä tapauksessa ohjautuvat omille työmarkkinoilleen tai seuraaviin toimintaohjelmiin. Vaikka alan asiantuntijat tuskin pitävät etenkään nuorten ja aikuisten erityispedagogisia palveluja riittävinä tarpeisiin verrattuna, Suomi lienee esikuvallinen niiden kehittämisessä. Valtavirtaan integroinnissa on pyritty pois erillisistä laitoksista tai viety erityisoppilaitosten asiantuntijuutta valtavirran oppilaitoksiin tai niiden tukena toimiviin yksiköihin. Erityispedagogisessa tutkimuksessaja koulutuksessa on edetty peruskoulukeskeisyydestä myös nuorten ja aikuisten eri elämänalueilla tapahtuvan kasvun tarkastelemiseen.

$\mathrm{M}$ inulla on pitkä ura julkisen liikenteen kannattajana. Lukemattomat kerrat olen istunut rautatie- ja linja-autoasemien odotushalleissa ja kuppiloissa junaa tai bussia odottamassa. Jokin feromonini näyttää vetävän milloin minkinlaisia erilaisia aikuisia puoleensa ja harva se kerta käyn keskusteluja elämän iloista ja suruista, katkeruuksista ja toiveista. Aivan hiljan kuitenkin seurasin tapahtumaa, joka vieläkin saa hengityksen kiihtymään. Julkisesti näkyvän erilaisuuden alinta kastia lienee yhdistelmä vammainen ympärihumalainen nainen. Hän nuokahteli junan penkissä, puolipukeissa, ei ollut kyennyt vessaan tarpeilleen, kainalosauva kolisi käytävällä. Vaunussa matkustavien koostumus oli tavallinen: suurin osa keski-ikäisiä naisia, muutamia miehiä. Me naiset silmäilimme sammuneen suuntaan epäröiden, pudistellako halveksuen päätään vai noustako tutkimaan tilannetta. Yksi teki ratkaisun ja haki paikalle konduktöörin. Hän kohautti naista olkapäästä ja kehotti jämerästi nousemaan ja laittamaan housut jalkaan, soitti sitten poliisit paikalle. Me muut naiset aloimme puhua keskenään: ei se tuosta itse selviä. Miehet tuijottelivat tiukasti lehtiään tai ulos ikkunasta. Pari topakinta naista meni auttamaan vaatetta päälle ja yritti saada selville, minne matka. Paikalle tuli kaksi ladonkokoista poliisia, jotka jatkoivat konduktööriäkin tiukempaan sävyyn. Nainen soperteli, onko hän tehnyt jotain pahaa. Poliisit kantoivat 
hänet päästä ja jaloista roikottaen portaita alas, pää vain kolisi, ja pudottivat laiturille puolipukeissaan. Pikkuautoonsa eivät ottaneet, jäivät odottamaan Mustaa Maijaa. Moni meistä vaisusti äänteli, ettei noin saa ihmistä kohdella ja tuo on heitteille jättöä. Juna lähti ja hetken tuohtumuksen jälkeen naisten yhteys katosi.

Onko erilaisuus ongelmaisten oppijoiden lintuinfluenssa, joka tehokkaimmin hallitaan erityisasiantuntijoiden lääkäröinnillä? Vai ovatko aikuisten maailman - koulutuksen, työelämän, kansalaistoiminnan valtavirran - normaliteetit sairaita? Onko oikein jättää erilaisuuden diagnosointi ja käsittely aikuiskasvatuksen eri muotojen valtavirran ulkopuolelle? Kaikessa kasvatuksessa huolenpidon ja hallinnan, terveen ja sairaan, auttamisen ja alistamisen eron tai rajan tekeminen on perustava eettinen kysymys. Aikuiskasvatuksen erityishaaste on aikuisuuden hienotunteinen kunnioittaminen. Erityisasiantuntemuskin on aikuisuuden erilaisuuden kohtaamisessa varmasti tarpeen, mutta tarvitsevatko sitä enemmän koulutuksen, työelämän ja julkisuuden valtavirrassa soutajat kuin veneestä pudotetut? Junamatkani jatkui ristiriitaisissa ajatuksissa. Mikseivät julkishallinnon työntekijät osaa hoitaa ongelmaisia aikuisia ihmisarvoisella tavalla? Miksi miesmatkustajat käänsivät päänsä pois? Onneksi keski-ikäisistä naisista sentään löytyy vielä kriittinen massa, joka arvostaa huolta pitävää kansalaisuutta. Mutta mitä seuraavilla matkoilla mahtaakaan tapahtua? 